\title{
Pre- and Post-Harvest Practices and Varietal Preferences of Tomato in Ghana
}

\author{
Leander D. Melomey ${ }^{1,2}$, Mathieu A. T. Ayenan ${ }^{1,3} \mathbb{D}$, George Marechera ${ }^{2}$, Pearl Abu ${ }^{1}$, Agyemang Danquah $1,4, * \mathbb{C}$, \\ David Tarus ${ }^{2}$ and Eric Y. Danquah ${ }^{1,4}$ (B)
}

1 West Africa Centre for Crop Improvement, College of Basic and Applied Sciences, University of Ghana, Legon PMB 30, Ghana; lmelomey@wacci.ug.edu.gh (L.D.M.); mayenan@wacci.ug.edu.gh (M.A.T.A.); plabu@wacci.ug.edu.gh (P.A.); edanquah@wacci.ug.edu.gh (E.Y.D.)

2 African Agricultural Technology Foundation (AATF), Nairobi P.O. Box 30709-00100, Kenya; G.Marechera@aatf-africa.org (G.M.); d.tarus@aatf-africa.org (D.T.)

3 World Vegetable Center, West and Central Africa-Coastal and Humid Regions, IITA-Benin Campus, Cotonou 08 BP 0932, Benin

4 Department of Crop Science, College of Basic and Applied Sciences, University of Ghana, Legon LG 44, Ghana

* Correspondence: adanquah@wacci.ug.edu.gh; Tel.: +233-0307-079427

check for updates

Citation: Melomey, L.D.; Ayenan, M.A.T.; Marechera, G.; Abu, P.; Danquah, A.; Tarus, D.; Danquah, E.Y. Pre- and Post-Harvest Practices and Varietal Preferences of Tomato in Ghana. Sustainability 2022, 14, 1436. https://doi.org/10.3390/su14031436

Academic Editor: Flavio Boccia

Received: 23 September 2021

Accepted: 10 December 2021

Published: 27 January 2022

Publisher's Note: MDPI stays neutral with regard to jurisdictional claims in published maps and institutional affiliations.

Copyright: (C) 2022 by the authors. Licensee MDPI, Basel, Switzerland. This article is an open access article distributed under the terms and conditions of the Creative Commons Attribution (CC BY) license (https:// creativecommons.org/licenses/by/ $4.0 /)$.

\begin{abstract}
Tailored interventions in the tomato sector require current information on production and marketing systems along with the constraints faced by the stakeholders. We conducted this study to understand the current production practices, stakeholders' varietal preferences, tomato market trends, and challenges along the crop's value chains. A multistage sampling method coupled with a random walk was used to identify survey locations and identify 180 respondents across seven regions in Ghana. The study showed that tomato was predominantly produced by male (81\%) and literate farmers (84\%). Tomato farmers were smallholder farmers generally cultivating less than five acres. Tomato was mainly cultivated under rainfed conditions. Farmers used both bought seeds and their own saved seeds for production. Farmers in Bono, Greater Accra, and the Upper East region largely cultivated improved tomato varieties, while farmers in the Bono East region cultivated local varieties. Across the regions, being a male and having access to irrigation facilities increased the probability of using improved varieties by $19 \%$ and $51 \%$, respectively. The most important farmer and market preference criteria included high yield, medium to large fruit size and rounded fruit shape, red color, time to maturity and disease resistance. The major production challenges of tomato production included diseases, pests, and poor access to water for irrigation. The average yield of tomato varied from $6902.26 \mathrm{~kg} / \mathrm{ha}$ in the Bono Region to $16,213.98 \mathrm{~kg} / \mathrm{ha}$ in Bono East. Tomato was exclusively produced for fresh market. The major marketing challenges were low producer prices, low demand for produce, and competition from other farmers. This study provides key information to improve tomato value chains and guide the introduction or breeding of improved tomato varieties.
\end{abstract}

Keywords: Solanum lycopersicum; production practices; market preferences; production constraints; marketing constraints

\section{Introduction}

Vegetable production is an important component of global agricultural system, as it contributes to food and nutrition security, income generation, and employment creation [1,2]. Tomato (Solanum lycopersicum L.) is the second most important economic vegetable produced in the world in terms of land area under cultivation and consumption. The world total fresh tomato production was approximately 180 million tonnes in 2019 on 5 million hectares of land. Similarly, Ghana produced 395,755 tonnes on 92,045 ha of land in 2019 [3]. On the other hand, the annual estimated tomato consumption in Ghana was approximately 400,900 tonnes $[4,5]$ which was more than the country's domestic supply. To meet the demand of tomato and tomato products (peeled tomato, juice, and paste), Ghana imported 8753 tonnes of fresh tomato at a value of approximately US $\$ 1.84$ million, and 
57,971 tonnes of tomato product valued at US $\$ 47.37$ million [3]. Burkina Faso had $89 \%$ market share in Ghana's tomato imports [6]. The trade values might be higher than official figures reported due to the poor trade data quality and underreporting as alluded to by Van Asselt, et al. [4]. Ghana's high tomato production volumes, coupled with high imports of tomato and tomato products, underscore the importance of tomato in the country. It is important to note that despite interventions by successive governments to establish tomato processing factories in the country, they remain shut down due to the unavailability of the required quantity and quality of tomato varieties [7]. Sustainable tomato production and processing in Ghana presents an untapped potential for boosting economic growth and job creation among the unemployed youth [8].

In the coastal areas of West Africa, tomato production is seasonal, since most of the production is rainfed, and there is limited availability of heat-tolerant varieties for offseason production $[9,10]$. This seasonality leads to a severe shortage of the produce during the dry season and prices skyrocket, compromising tomato stability and accessibility for consumers. On the contrary, there is glut during the rainy season, and, in most cases, farmers abandon their fields when prices are so low. Farmers continue to grow tomato during the rainy season because it is relatively cheaper to produce during the rainy season and hope that their harvest will meet higher prices. Considering the edaphic, weather, and other growth requirements of tomato, many regions in Ghana are suitable for tomato production [11]. There is a steady decline in yield, although production is increasing due to increases in areas under cultivation. The average yield of tomato in Ghana is $4.30 \mathrm{t} / \mathrm{ha}$ compared to $10.86 \mathrm{t} /$ ha of the neighboring country, Burkina Faso, and the $35.93 \mathrm{t} / \mathrm{ha}$ produced globally [3]. The poor yields could be attributed to several production constraints including diseases, pests, abiotic stresses, access to improved seeds and inputs, and other production factors (e.g., irrigated land). Post-harvest handling of tomato is also a major challenge to overall tomato productivity. This is because tomato is highly perishable, and due to a lack of cold storage in Ghana, produce rots in farmers field when there is glut during the rainy season. Pre- and post-harvest losses of vegetables could be as much as $50 \%$ [8], underscoring the non-sustainable nature of the current production and post-harvest practices.

Improvement of tomato production and post-harvest management will create additional opportunities for farmers to increase their income, improve livelihoods, as well as revamp the processing plants to create job for the youth. To achieve this improvement in tomato productivity and post-harvest handling, there is the need to comprehensively evaluate the current tomato production practices, perception of farmers on the prevailing conditions and constraints of tomato production, the opportunities for tomato production, yield improvement, storage, and marketing. Moreover, understanding drivers of the use of improved tomato varieties will guide interventions seeking to promote new varieties. The information generated in through this study will be critical to the value chain actors such as farmers, transporters, marketers, seed companies, researchers, private sectors, extension agents, government sectors, and policymakers to design effective value chain development strategies to increase domestic production of vegetables in the country. The objectives of this study were to (a) document the farmers production practices, (b) determine the key factors influencing the use of improved tomato varieties, and (c) identify tomato production challenges, opportunities and enabling environment that can sustainably improve tomato production in Ghana.

\section{Materials and Methods}

\subsection{Study Area}

The study was carried out in the major tomato production regions in Ghana. The country has administrative regions which are subdivided into metropolitan/municipality/districts and then cities, towns, villages, and communities. The study locations covered seven regions namely, Ahafo, Ashanti, Bono, Bono East, Eastern, Greater Accra, and Upper East regions, which are well known for tomato production [7]. The survey was carried out in 12 villages 
in the seven regions, namely, Kofibadukrom in Dormaa Municipal district, Derma in Tano South district, Tuobodom in Techiman North district, Afrancho and Akumadan in Offinso North district, Asante Akyem Agogo in Asante Akyem North district, Begoro in Fanteakwa district, Ada Kasseh in Ada East district and Sege Kuloedor in Ada West district, Vea in Bolgatanga Municipal, Tono in Kasena Nankana district, and Pwalugu in the Talensi District (Figure 1, Table S1).

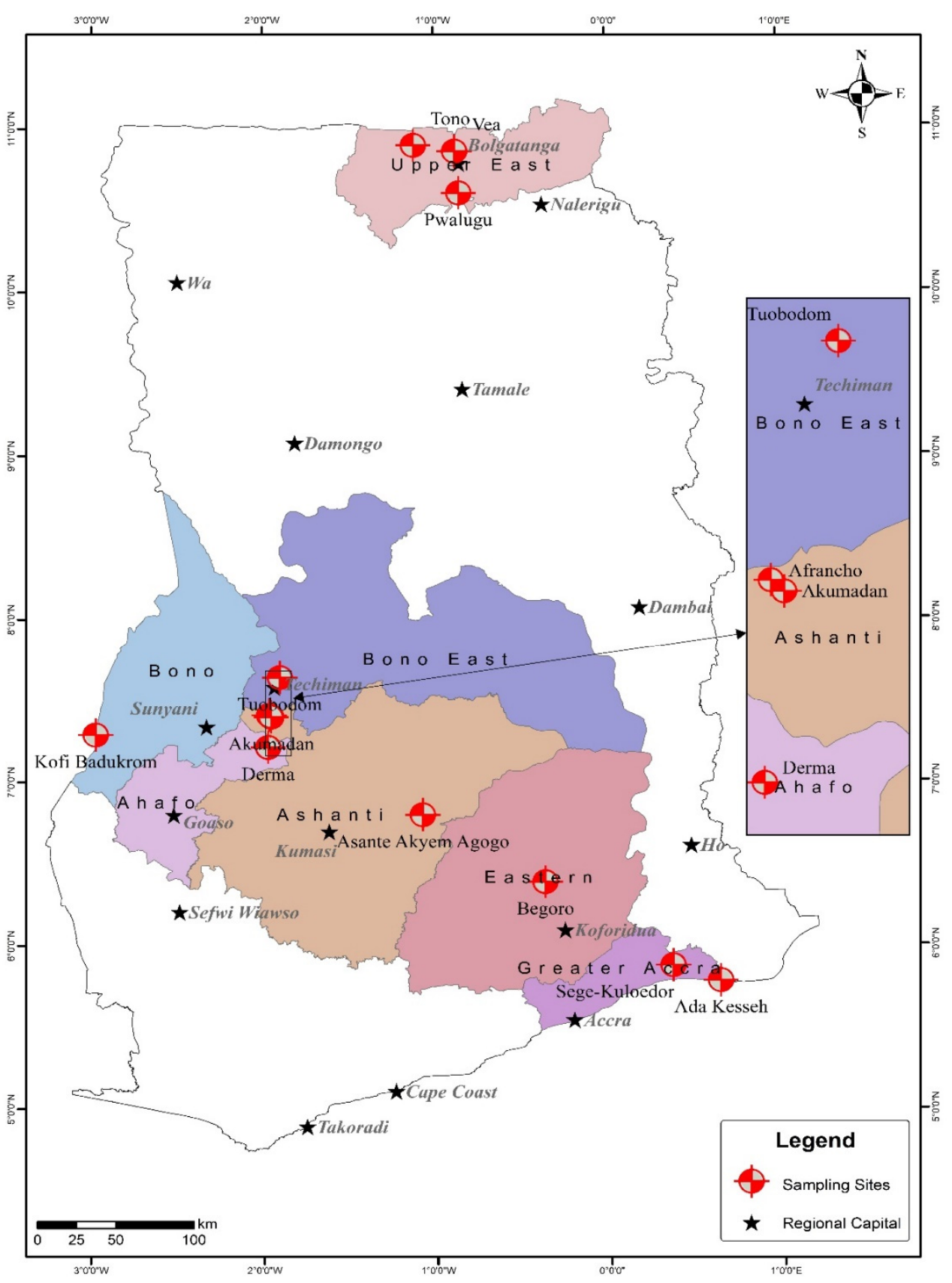

Figure 1. Map of Ghana showing study regions of high tomato productivity.

\subsection{Sampling Methods}

The study was conducted in seven regions in Ghana using a multistage sampling method. Selection of the survey locations comprised of identification of major tomato growing regions as the first stage based on production statistics. Within these regions, districts (second stage) and villages (third stage) were identified based on experts (agriculture extension agents, as well as tomato breeders and traders) recommendations and produc- 
tion statistics. The fourth stage consisted of the random selection of communities from each village. The fifth stage entailed randomly selecting specified numbers of households from the selected communities cultivating tomato in each district. In these communities, almost every household had a member cultivating vegetables, including tomato. A total sample size of 180 tomato farmers was interviewed in the seven regions, 12 districts or municipalities, and 12 villages in Ghana in August 2020 (Table S1). The distribution of tomato farmers across regions in Ghana varies from one region to the other. Some regions have more tomato farmers due to the favorable conditions, as well as the availability of irrigation facilities [12] and access to credit facilities [13]. Based on the density of farmers per region, we selected more farmers in particular regions than others. The sample size per region varied between $15-50$ farmers per region.

\subsection{Data Collection}

Primary and secondary data were collected in this study. The primary data was collection from farmers involving face to face interviews, focus group discussions, and questionnaires with closed and open-ended questions. The closed and open-ended questionnaires were designed based on KoBoToolbox [14] and administered with a tablet or smartphone using the KoboCollect app [15]. The data collected were uploaded and saved to a central server. This allowed for real-time data monitoring and data quality checks while data collectors were in the field. In each village, questionnaires were administered to the head of the household in a face-to-face interview. Respondents were asked their willingness to participate in the survey, whether they were tomato farmers, their household's socio-economic characteristics and demographic profile, access to land, general farming systems, varieties grown, propagation methods, production system, inputs used, cost of production, harvesting of tomatoes, extension training and support, marketing, transportation, and constraints.

\subsection{Data Analysis}

The quantitative and qualitative data analyses were carried out using Excel 2016 and Statistical Package for Social Science (SPSS) version 20. Data were presented using statistical summaries, graphs, and significant tests. Differences in average distance travelled $(\mathrm{km})$ to purchase seeds, average quantity of seeds purchased (g), amount (GHS, $1=\$ 5796$ ) spent on seed purchase, yield across regions, and gender were assessed using Kruskal-Wallis test, followed by a pairwise Wilcoxon test for mean separation in MVapp [16].

We used logistic regression to assess the factors that could explain the use of improved tomato variety using the glm.fit function, and set the family argument to binomial in $\mathrm{R}$ 4.0.5 [17]. The following variables were used to build the model.

\subsubsection{Improved Varieties}

Use of improved variety was the response variable, and it was measured as a binary variable. Farmers who used improved varieties were assigned the code 1, and those who did not use were assigned 0 .

\subsubsection{Gender}

Women and men do not have equal access to production factors, including seed. The use of improved seed is expected to be male-biased. Gender was measured as a dummy variable, where males and females were assigned 1 and 0 , respectively.

\subsubsection{Education}

Education has been reported to influence the adoption of technologies. We expect that literate farmers are more likely to adopt and use improved varieties compared to non-literate farmers. Education was coded as a dummy variable, with literate (1) and non-literate (0). 


\subsubsection{Training}

In this study, training refers to the participation (1) or not (0) of farmers to capacity building organized by extension agents. It is expected that farmers who received training would be more exposed to the benefits of improved varieties, and are more likely to use them.

\subsubsection{Irrigation}

Irrigation is a key component of tomato production. Farmers who use irrigation (1) are expected to be more likely to use improved varieties compared their fellow who do not (0).

\section{Results and Discussion}

\subsection{Household Socio-Economic Characteristics and Demographic Profiles}

The summary of the descriptive statistics of all farmers sampled $(n=180)$ is presented in Table 1. The production of tomato in Ghana was not gender exclusive, but most of the respondents were males (81\%) compared to females $(19 \%)$. This statistic is similar to the findings of the Ghana Statistical Service, where $78.1 \%$ and $28.9 \%$ of males and females, respectively, were engaged in arable crops production [18]. Most of the farmers (47\%) were between the ages of 34 and 49 years. Agriculture sustainability depends on the youthful population in the farming communities. It is therefore encouraging to discover that there was quite significant number of youths in tomato production, and most farmers were in their most productive years (less than or equal to 60 years).

Most $(89 \%)$ of the tomato farmers had some level of education or could read and write. This finding is consistent with that reported by Osei, et al. [19] for tomato farmers in Ghana. The farmers mainly attended primary (19\%), junior secondary $(41 \%)$, and senior secondary $(17 \%)$ schools. The literacy rate of tomato farmers was higher than that of farmers $(50.5 \%)$ engaged in arable crops farming [18]. The high literacy among tomato farmers could be an advantage in terms of utilization of information in sustainable production and marketing of produce. In fact, education improves the ability to receive, decode, and understand information [20], which is critical in increasing agricultural productivity [21]. Besides, evidence from northern Ghana revealed that literacy positively affects farmers' access to credit [20]. The household type that was predominant in tomato growing communities in Ghana was male headed with one wife $(81 \%)$. Households that were headed by female were either because the female was divorced, single, or widowed $(6 \%)$, or the husband was absent $(1 \%)$. The land for the production of crops in the survey regions were largely owned by male heads $(65 \%)$. Higher proportion of male owning land compared to female ownership was reported in several studies in Ghana [20-23]. Understanding land ownership is critical to agriculture productivity since primary land ownership is positively associated with decisions on land allocation to crops and technology adoption [22,24]. Kudadze, et al. [25] maintained that irrigation farming in Ghana is very limited, which was confirmed in this study, where $60 \%$ of the farmers did not have access to irrigation. Similar results were reported by van Asselt, et al. [4]. Our study revealed that tomato was partially produced under irrigation in the Greater Accra Region and the Upper East region. Investing in small scale irrigation along with the adoption of adapted varieties would promote sustainable year-round production through greater availability, stability, accessibility, and use [26]. Increasing investment in tomato would also increase economic returns and improve nutrition.

Not surprisingly, the main occupation of the respondents (91\%) across the seven regions in Ghana was crop farming. Being mostly crop farmers, the three major crops grown by the respondents were tomato (29\%), pepper (22\%), and maize (20\%) (Figure 2 ). This could be attributed to the fact that maize is a major staple crop, while tomato and pepper are the most important vegetable crops in Ghana. 
Table 1. Sociodemographic and farm characteristics of tomato farmers in seven regions of Ghana.

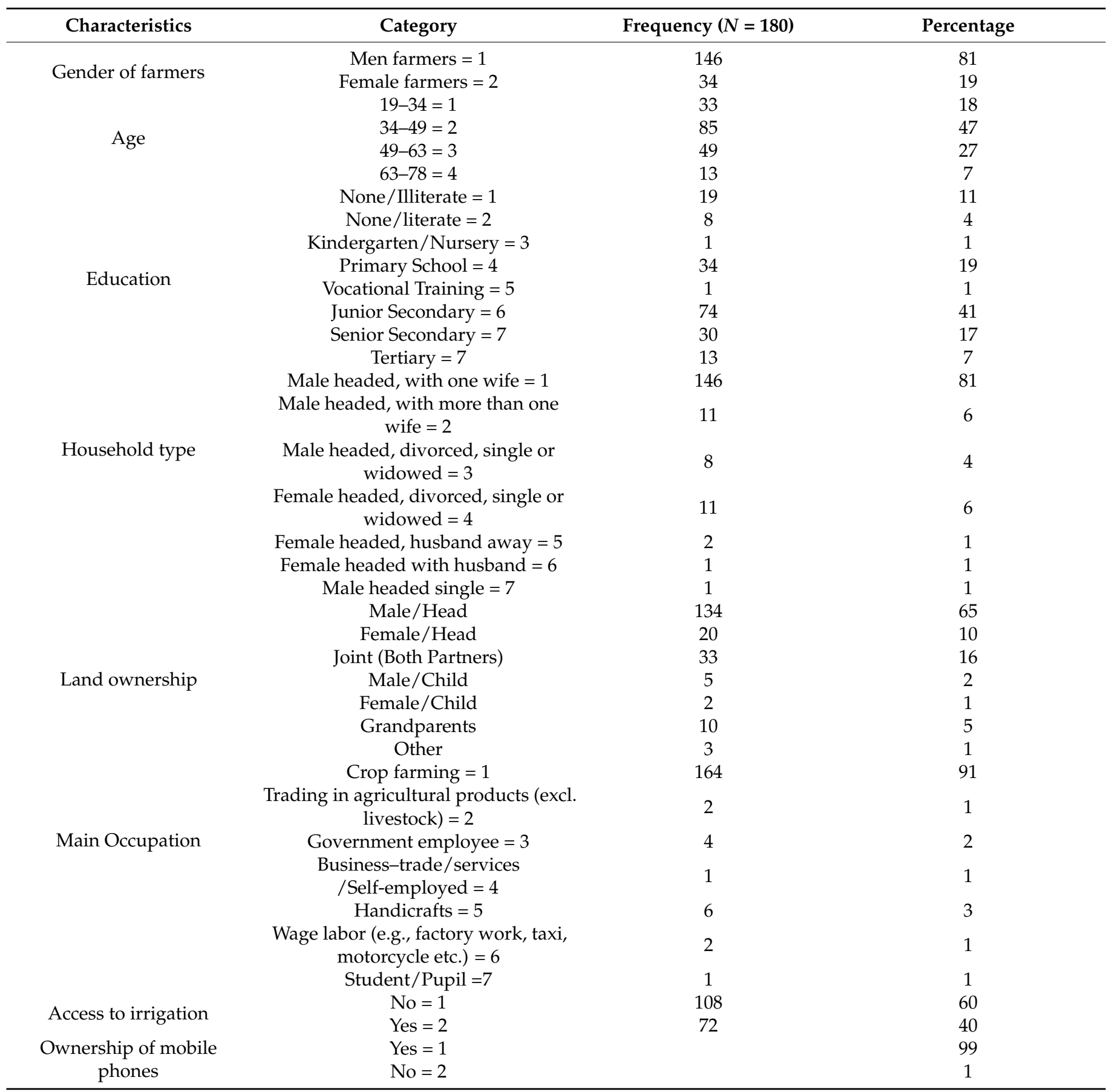




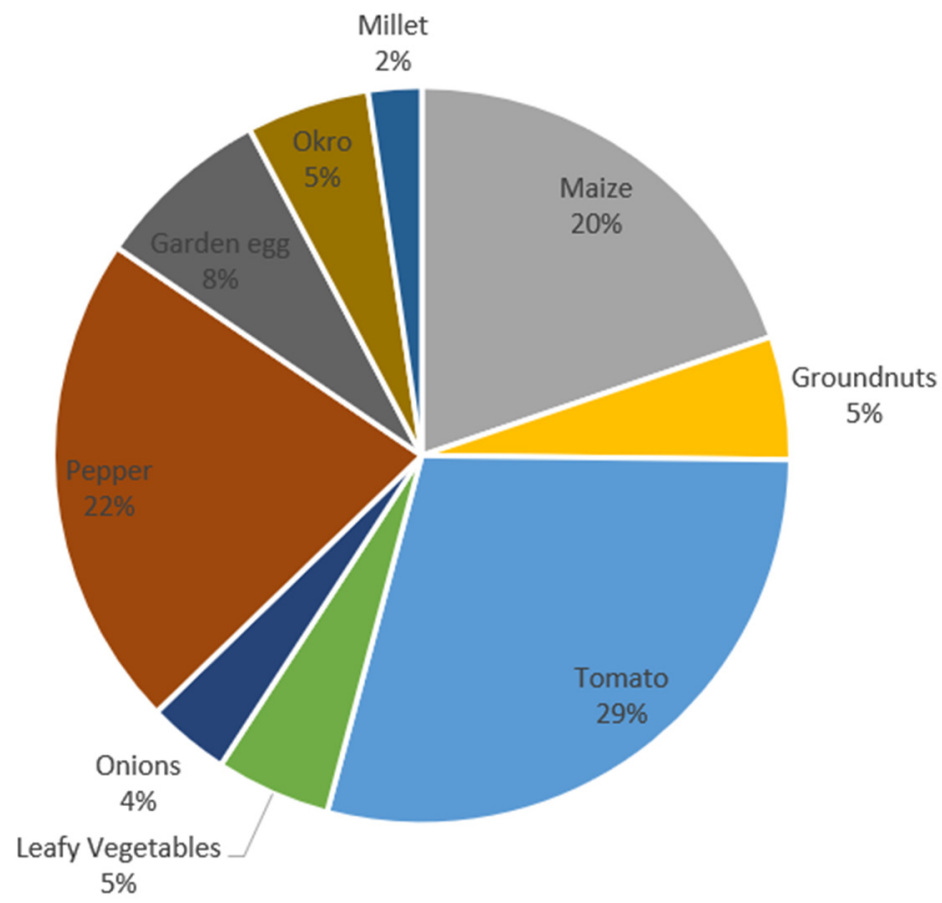

Figure 2. Crops grown by tomato farmers in Ghana.

The advancement in communication technology over the past decade has been phenomenal. This was evident in the ownership of mobile phones among almost all respondents (99\%), despite the fact that they lived in rural areas. The ownership of mobile phones is a useful resource for households to have access to information on market and extension advice. For instance, in Ghana, the ownership and use of mobile phones to access extension services for the adoption of modern production technology and market participation has been credited for improved maize productivity [27]. Subsequently, access to information has been reported to improve smallholder farmers' price forecasting accuracy and farmers' welfare [28]. Moreover, the use of mobile phones can potentially enable farmers to have access to agro-meteorological information [29], thereby allowing them to improve their adaptive capacity to climatic hazards.

The result from this study revealed no significant difference $(p>0.05)$ in the size of land cultivated by male and female tomato farmers (Table 2), even though males had land sizes of approximately double that of women. Eighty nine percent of the tomato farmers were cultivating less than or equal to two hectares of land, making them smallholder farmers. It is interesting to note that the findings affirmed assertions by Gebre, et al. [30]: in sub-Saharan Africa, agricultural production is mostly on a smallholder basis.

Table 2. Difference between male and female heads ownership of land size and size of land for tomato production in Ghana.

\begin{tabular}{cc}
\hline Gender & Land Size (Ac) Owned \\
\hline Male head & $14.70 \mathrm{a}$ \\
Female head & $7.65 \mathrm{a}$ \\
Male & Land size for tomato production (ac) \\
Female & $4.23 \mathrm{a}$ \\
\end{tabular}

Means followed by the same letters are not statistically different $(p>0.05)$. 


\subsection{Tomato Seed Systems}

In Ghana, both formal and informal seed production and delivery systems exist. However, the informal delivery system supplied $80 \%$ of major seeds used in the country. The formal seed system is based on the production and purchase of certified seeds, while the informal seed system is characterized by seed production and exchange (gift, purchase) among farmers at the local level [31].

\subsubsection{Sources of Tomato Seeds}

Depending on the genetic nature of tomato varieties (pure lines), seeds grown in one season can be extracted and regrown the following season without affecting yield. These varieties are usually cultivated over the years by farmers, without the need to buy new seeds, or can be obtained from other farmers or on local markets. On the other hand, there are some hybrid varieties that are mostly distributed by seed companies. The majority of tomato farmers $(65 \%)$ across the regions bought tomato seed, even though some farmers $(32 \%)$ relied on saved seeds (Table 3$)$. Tomato seeds were mostly bought from local shops or agro-dealer shops (73\%) in the communities. Most of them have developed the habit to purchase seeds, and this is in alignment with the previous report on vegetables in Ghana $[4,7]$. This finding is very encouraging for investing in improved seeds and seed distribution. It is worth noting that not all seeds sold at the agro-shops are improved seeds from seed companies. Some of the seeds sold were retained seeds procured from local farmers or mishandled because of poor storage conditions. Thus, the high percentage of farmers using bought seed does not translate into the same high percentage usage of quality or improved seeds. This trend of selling poor quality seeds by agro-dealers dilutes the effort of introducing improved seeds to farmers, as it creates distrust between farmers and seed companies. Some farmers bought seeds from their fellows, while a limited number of farmers $(6 \%)$ accessed seeds directly from the seed companies. This is due to the unavailability of seed companies or their representatives in the communities. This could require developing and strengthening seed distribution channels in farming communities [32].

Table 3. Seed sources, distributors, and criteria for varietal selection.

\begin{tabular}{|c|c|c|c|}
\hline Characteristics & Category & $\begin{array}{c}\text { Frequency } \\
N=180 *\end{array}$ & Percentage \\
\hline \multirow{4}{*}{ Seed source } & Seed purchasing & 117 & 65 \\
\hline & $\begin{array}{l}\text { Seed saving and } \\
\text { purchasing }\end{array}$ & 4 & 2 \\
\hline & Seed saving & 58 & 32 \\
\hline & Other & 1 & 1 \\
\hline \multirow{4}{*}{ Seed supplies } & $\begin{array}{c}\text { Local } \\
\text { Shop/Agro-dealer }\end{array}$ & 86 & 73 \\
\hline & Other farmers & 23 & 19 \\
\hline & Seed companies & 7 & 6 \\
\hline & Supermarket in town & 2 & 2 \\
\hline \multirow{4}{*}{$\begin{array}{l}\text { Reasons farmers } \\
\text { purchase seeds from } \\
\text { suppliers }\end{array}$} & Cheaper seed & 13 & 7 \\
\hline & Assured of quality & 112 & 62 \\
\hline & Proximity/Nearness & 43 & 24 \\
\hline & Others & 12 & 7 \\
\hline \multirow{6}{*}{$\begin{array}{c}\text { Criteria for choosing } \\
\text { a variety }\end{array}$} & High yield & 56 & 29 \\
\hline & Fruit size & 48 & 25 \\
\hline & Color & 34 & 18 \\
\hline & Time to maturity & 24 & 12 \\
\hline & Resistance to diseases & 19 & 10 \\
\hline & Others & 13 & 7 \\
\hline
\end{tabular}


Understanding reasons underlying farmers' seed purchase behavior is important for the promotion of improved and good quality seeds. Farmers bought tomato seeds from suppliers because of assured quality $(62 \%)$, proximity to the seed supplier $(24 \%)$, and the relative cost of the seeds (7\%). Other reasons why farmers bought seeds from some suppliers included varietal attributes such as long shelf life, market preference, high yields, and adaptability to growing conditions. Similar findings were also reported by Osei et al. (2018) that tomato farmers adopted varieties based on the mentioned attributes. The most important factors farmers considered in choosing a variety was high yield $(29 \%)$ or the ability of a plant to produce many fruits, followed by fruit size $(25 \%)$, red fruit color $(18 \%)$, time to maturity $(12 \%)$, and resistance to diseases $(10 \%)$. Other factors farmers considered included adaptability to growing conditions, longer fruit shelf life, and high market demand. The identification of farmers' varietal preference is important to successfully introduce new varieties, and guide the breeding of adapted and varieties.

There were, however, varied dynamics in seed sourcing among the regions. Farmers in Bono (100\%), Eastern (90\%), Greater Accra (90\%), and Upper East (86\%) regions bought seeds for tomato cultivation whereas, farmers in the Ahafo (64\%), Ashanti $(60 \%)$ and Bono East (73\%) largely depended on retained seeds (Table 4). A multiplicity of factors accounted for the mixed trend. The variety planted by farmers in these regions coupled with the ability of fruits to produce viable seeds that could also yield highly, as the bought seeds determined whether farmers used retained or bought seeds. The farmers' decision as to which seeds to plant was economically tainted with insurance. They bought seeds that could be saved, thus enabling them not to buy new seeds in subsequent seasons. In addition, if the farmer could not afford improved seed during the next planting season, the saved seeds could be planted. The regions with higher percentages of farmers buying seeds mostly cultivated improved varieties. The regions with higher percentages of farmers saving seeds mostly cultivated unimproved varieties that renewed their seeds, such as the Petofake, Power, and other local varieties.

Table 4. Sources of seeds for tomato production in seven regions in Ghana.

\begin{tabular}{|c|c|c|c|c|c|c|c|}
\hline $\begin{array}{l}\text { Sources of } \\
\text { Seeds (\%) }\end{array}$ & $\begin{array}{l}\text { Ahafo } \\
N=15\end{array}$ & $\begin{array}{c}\text { Ashanti } \\
N=45\end{array}$ & $\begin{array}{c}\text { Bono } \\
N=15\end{array}$ & $\begin{array}{c}\text { Bono East } \\
\quad N=15\end{array}$ & $\begin{array}{c}\text { Greater } \\
\text { Accra } \\
N=20\end{array}$ & $\begin{array}{l}\text { Eastern } \\
N=20\end{array}$ & $\begin{array}{l}\text { Upper East } \\
\qquad N=50\end{array}$ \\
\hline Purchase seed & 29 & 36 & 100 & 20 & 90 & 90 & 86 \\
\hline $\begin{array}{c}\text { Saved and } \\
\text { purchase seed }\end{array}$ & 7 & 4 & 0 & 7 & & 10 & 14 \\
\hline Saved seed & 64 & 60 & 0 & 73 & 10 & 0 & 0 \\
\hline
\end{tabular}

\subsubsection{Seed Purchase Habits of Tomato Farmers}

Generally, some farmers in the Ashanti, Eastern, and Greater Accra regions had to travel long distances to purchase seeds (Table 5). The quantity of seeds bought in the Ahafo and Greater Accra region was considerably high. This could be directly related to the land size that farmers cultivate. However, the amounts of seeds bought by farmers in the Greater Accra region was significantly higher than all regions including Ahafo, since most farmers in the Greater Accra region, cultivated improved varieties whose prices are undoubtedly higher than unimproved varieties. The fact that farmers had to travel long distances to purchase seeds revealed that farmers were still constrained by seed availability and accessibility issues [33]. 
Table 5. Quantities of seed purchased by tomato farmers in Ghana.

\begin{tabular}{cccc}
\hline Regions & $\begin{array}{c}\text { Average Distance } \\
\text { Travelled } \mathbf{( k m )}\end{array}$ & $\begin{array}{c}\text { Average Quantity of } \\
\text { Seeds Purchased (g) }\end{array}$ & Amount (GHS) \\
\hline Ashanti & 55.96 & $215.00 \mathrm{~b}$ & $192.08 \mathrm{~b}$ \\
Greater Accra & 28.00 & $793.33 \mathrm{a}$ & $811.00 \mathrm{a}$ \\
Eastern Region & 12.38 & $280.00 \mathrm{~b}$ & $235.62 \mathrm{~b}$ \\
Upper East & 5.62 & $222.73 \mathrm{~b}$ & $134.16 \mathrm{~b}$ \\
Ahafo & 2.38 & $720.00 \mathrm{ab}$ & $263.75 \mathrm{~b}$ \\
Bono & 1.48 & $153.33 \mathrm{~b}$ & $186.33 \mathrm{~b}$ \\
Bono East & 0.40 & $102.50 \mathrm{~b}$ & $90.00 \mathrm{~b}$ \\
\hline
\end{tabular}

For the same variable, means followed by the same letters are not significantly different $(p>0.05)$.

\subsection{Varietal Diversity and Preferred Tomato Attributes}

The tomato varieties grown in Ghana varies from one region to the other, although some varieties are common across regions (Figure 3). In the Ahafo region, farmers cultivated unimproved varieties called local and petofake. In the Ashanti region, the varieties grown were generally unimproved varieties such as Konkon (78\%), Petofake (11\%), Power Rano $(2 \%)$, and Power $(1 \%)$, in addition to an improved variety Petomech $(6 \%)$. The varieties grown in Bono East were two local varieties: Power Rano (73\%) and Power (27\%). Farmers in the Bono region cultivated improved varieties such as BS (47), France seed (13\%), Petomech (13\%), Cobra (7\%), Italian seed (7\%), Petomech GSN (7), and Petomech France $(7 \%)$. Farmers in the Eastern region cultivated local varieties such as Cocoa $(60 \%)$, Konkon $(30 \%)$, Power ntiawa (5\%), and an improved hybrid variety, Jaguar (5\%). In the Greater Accra region, the farmers cultivated improved varieties such as Cobra (65\%), M1 \& M2 (5\%), Roma (5\%), Padma (5\%), Petomech (15\%), and a Local variety (5\%). The main varieties grown in the Upper East region were improved varieties, which included Petomech (22\%), Roma (12\%), Tropimech ( $2 \%)$, and a local variety, Akumadan (4\%). A variety known as 'No name' was also grown. The varieties referred to as "Akumadan" grown in Upper East might have been introduced from Akumadan (Ashanti region). There was observed dependency between regions and varieties, with similar findings highlighted by van Asselt, et al., (2018). This could further be explained by the fact that farmers grew varieties for which seeds are available in their communities. As such, farmers may have limited decision power on the choice of variety, but they would rather depend on available varieties at agro-dealers' shops. Introduction and dissemination of climate-smart varieties would be necessary, as data highlighted that the unimproved varieties such "Power" were grown due to the ability to thrive in the face of rainfall variability. It is important to state that farmers chose varieties based on their adaptability rather than market preference. It is thus not surprising that most farmers indicated low demand for their tomatoes by fresh market buyers. The farmers perceived most of the varieties grown as having either medium or large fruit size (Figure 4). 


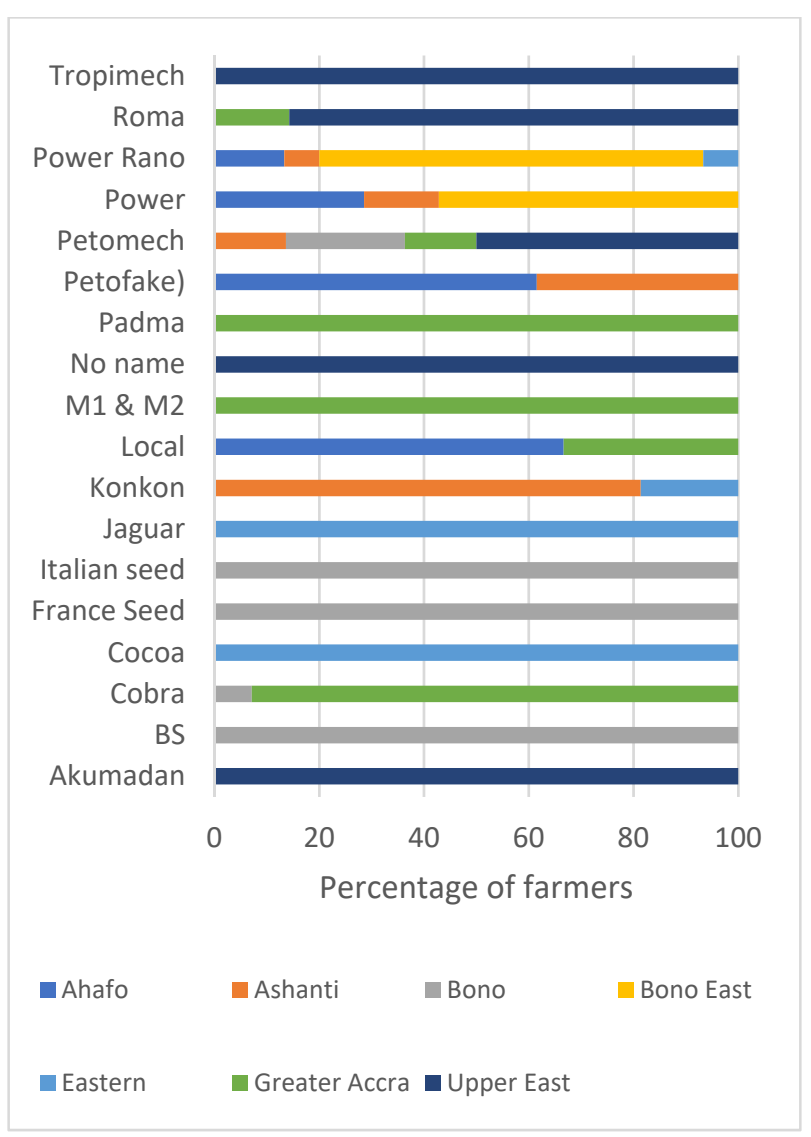

Figure 3. Tomato varieties grown in the different regions in Ghana.

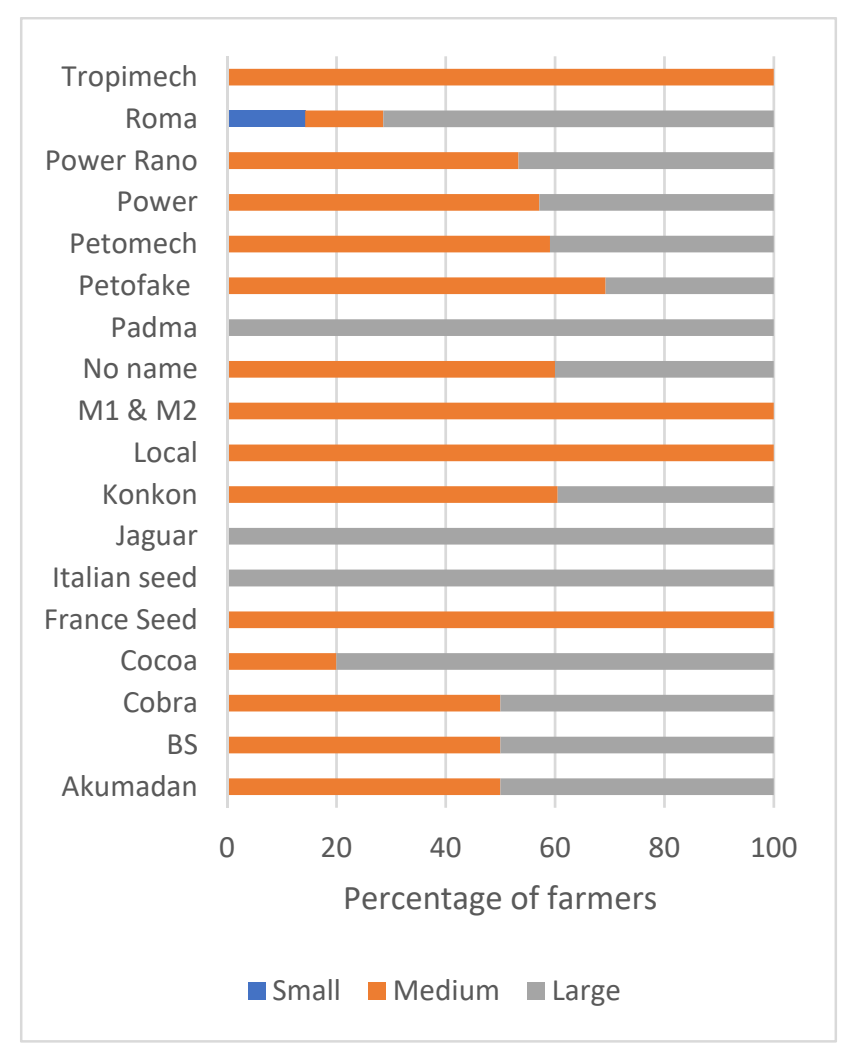

Figure 4. Farmers' perception of fruit size of tomato varieties in Ghana. 
The shape of tomato fruits plays a significant role in market preference. Farmers perceived the fruit shapes of Tropimech, Roma, Power, and Cobra as rounded (Figure 5). The following varieties were generally perceived as high rounded: Petomech, Petofake, Jaguar, Italian seed, France seed, Cocoa, and BS. Power Rano, Local and Akumadan were generally flattened, while Konkon was perceived as a mixture of different shapes. There were varieties (e.g., Roma, Akumadan) that were perceived as having both large, medium, or large fruit size, or having different fruit shape (e.g., konkon). This could be due to differences in growing and environmental conditions, or a different perception of the fruit size. The naming of the varieties was based on folk taxonomy. As a result, different varieties especially the local ones could be named differently, or the same name could be given to different varieties across regions [34].

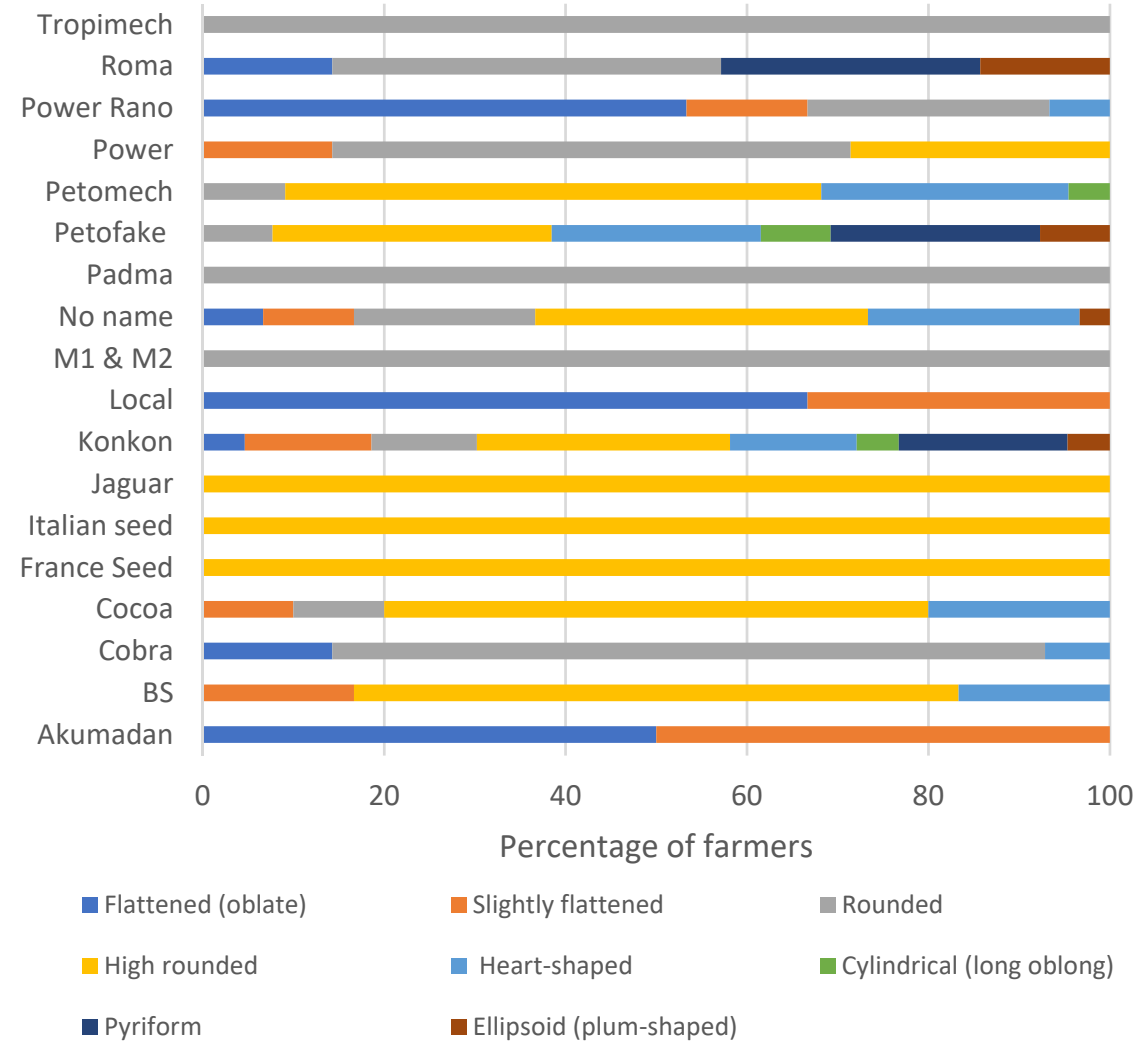

Figure 5. Variation of tomato fruit shapes.

\subsection{Tomato Production Season and Practices}

Tomato is mostly produced in the open field and supplied to the fresh market. There was an emerging trend in greenhouse tomato production in the country.

\subsubsection{Tomato Planting Season}

Tomato could be produced throughout the year in Ghana. However, the major planting seasons were March-July and August-December (Figure 6). Nurseries for both seasons can begin late February-mid march and mid-July-late July, respectively. This corroborated the findings of Robinson and Kolavalli [7], who reported that, within the year, different regions in Ghana produce tomato at different times of the year, with the Upper East region supplying tomato to the market from December/January to March, Brong Ahafo region (which has now been divided into the Ahafo, Bono, and Bono East) and Ashanti region supplying tomato to the market from June until November, and the irrigated tomato from the Greater Accra region dominating the market from November to December. Due to the low production from the Upper East and Greater Accra regions from December to May, Ghana imports fresh tomato from Burkina Faso during this period. 


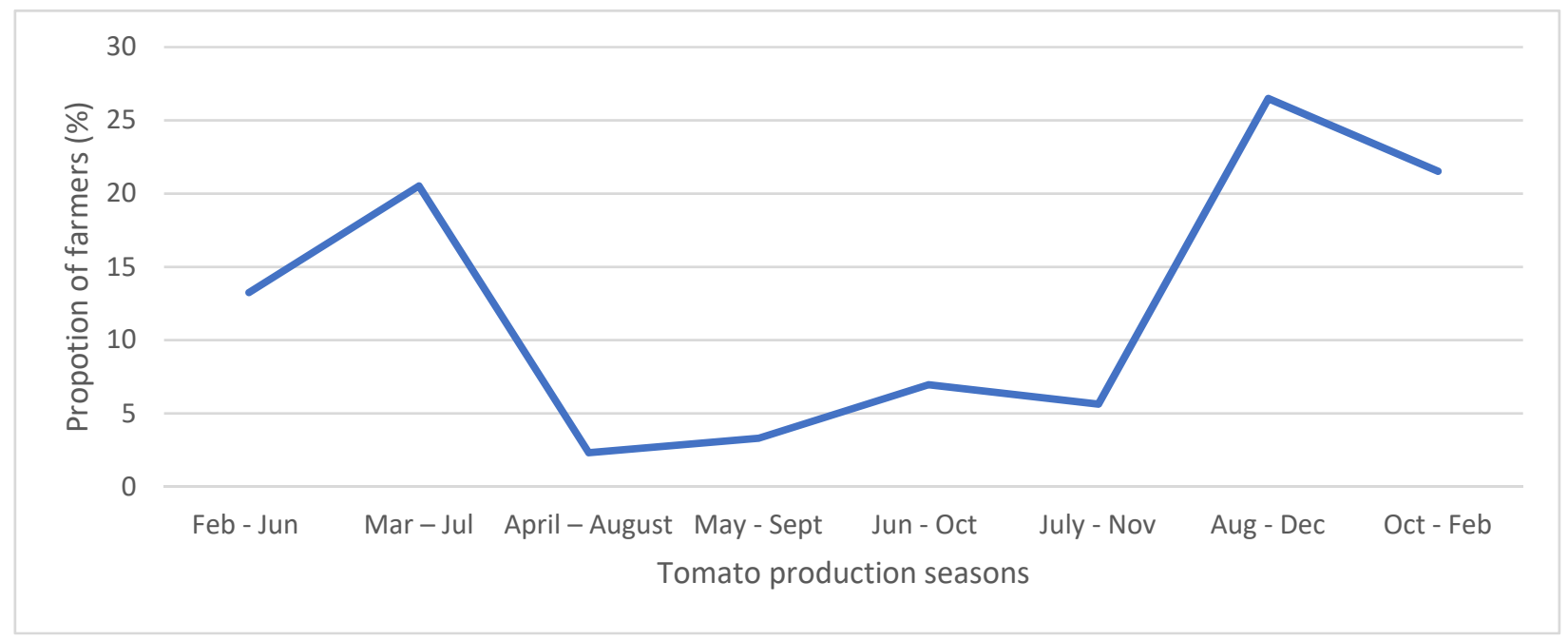

Figure 6. Tomato planting seasons in Ghana.

Farmers gave different reasons for planting at a specific period (Figure 7). These mainly included synchronization of production seasons with the rainy season to lower production cost to reduce the need for irrigation and its associated cost, and the desire to continuously supply the tomato market throughout the year. Although tomato can be produced year-round, there is generally a tomato supply gap from February till late May or early June, when the tomato is harvested in the middle and southern part of the country [7]. This shortfall period presents a business opportunity for greenhouses in the country to produce tomato for the domestic market. Moreover, the shortfall can be addressed if irrigation systems across regions are improved, and climate-resilient varieties (heat tolerant) and disease resistant are identified, introduced, or bred and disseminated.

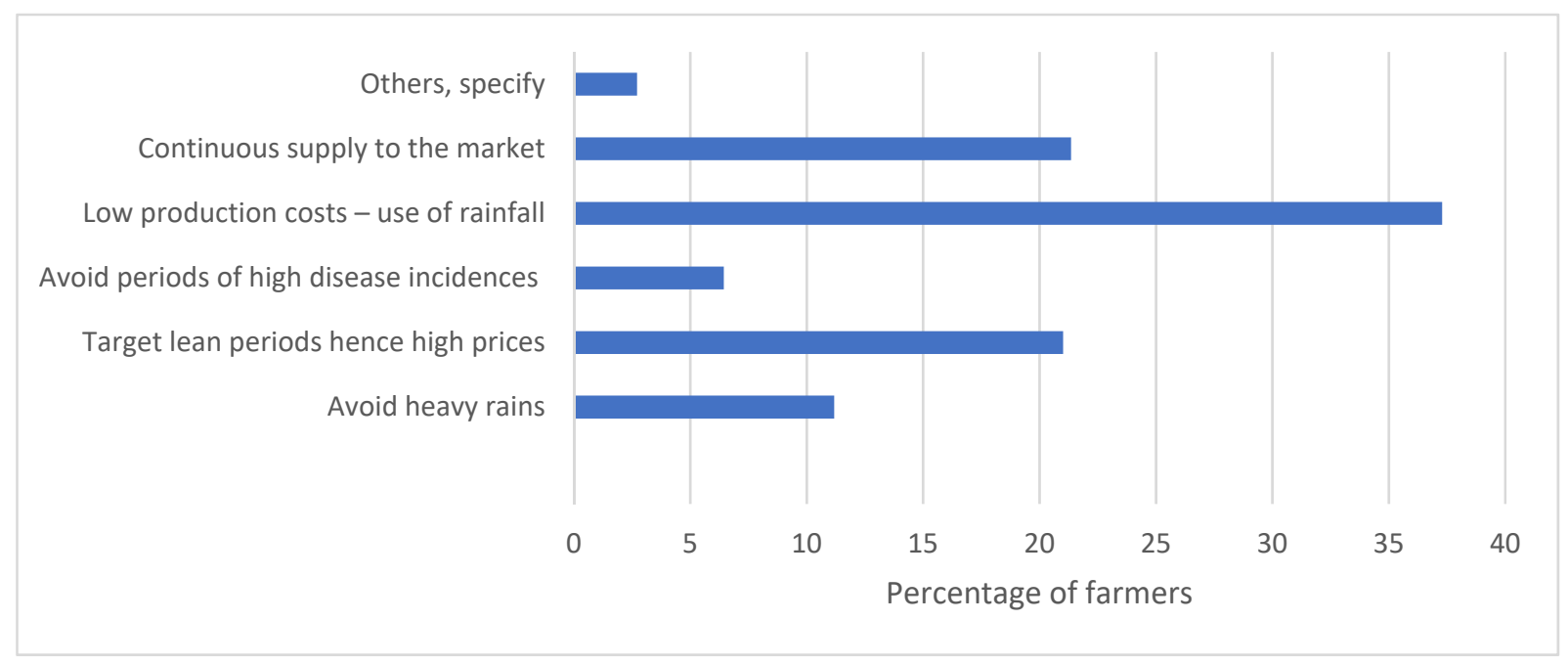

Figure 7. Farmers reasons for growing tomato at a particular planting season in Ghana.

Many tomato farmers in Ghana were smallholders with land sizes between one-two acres or less (Figure 8). Most of these farmers were predominant in the Ahafo and Greater Accra Regions. All of the respondents grew tomato in the open fields, which was the main tomato cropping system not only in Ghana, but also throughout Sub-Saharan Africa. 


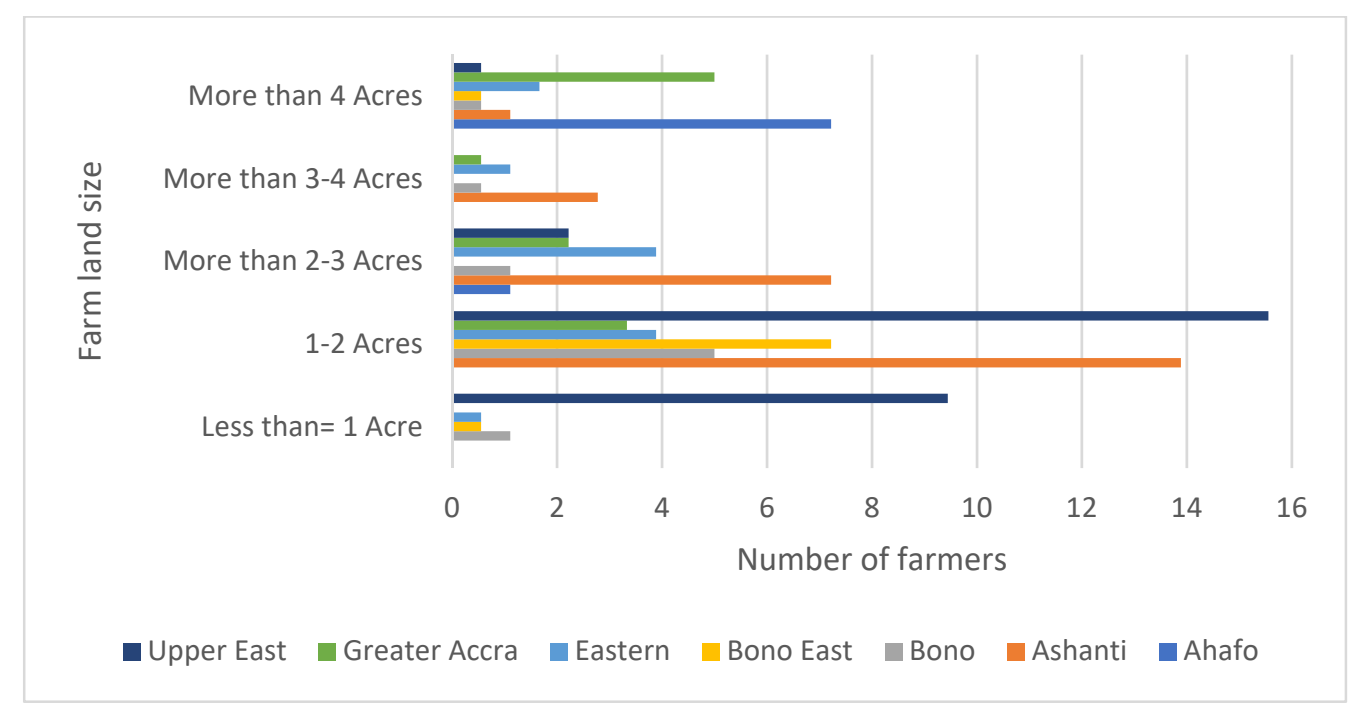

Figure 8. Tomato planted area per region.

\subsubsection{Tomato Seedling Handling}

Tomato was propagated with seeds, and farmers could either raise their nursery or buy seedlings that were ready for transplanting. It was realized that almost all of the farmers in our study areas established their nurseries on seedbeds (98\%) or with a few using seed trays (Table 6). Farmers preferred nursery beds since their construction could be performed near the farm $(57 \%)$, the bed was a relatively cheaper option (25\%), and it was established close to water source. Some farmers nursed in seed trays because it was easier to transplant $(43 \%)$, easier to transport (29\%), had high seedling establishment (14\%), and less disease incidence (14\%). Many farmers (57\%) transplant four to six weeks after nursing.

Table 6. Nursery practices among tomato farmers in Ghana.

\begin{tabular}{|c|c|c|c|}
\hline Characteristics & Category & $\begin{array}{c}\text { Frequency } \\
\qquad N=180\end{array}$ & Percentage \\
\hline \multirow[t]{2}{*}{ Sources of seedlings } & Own nursery & 180 & 100 \\
\hline & Commercial nursery & 0 & 0 \\
\hline \multirow{2}{*}{ Nursery methods } & Seedbed & 176 & 98 \\
\hline & Seed trays & 4 & 2 \\
\hline \multirow[t]{4}{*}{ Reasons for using seedbeds } & Cheaper & 65 & 25 \\
\hline & Established near field & 149 & 57 \\
\hline & $\begin{array}{l}\text { Established near } \\
\text { water source }\end{array}$ & 46 & 18 \\
\hline & $\mathrm{N} / \mathrm{A}$ & 2 & \\
\hline \multirow[t]{5}{*}{ Reasons for using seedbeds } & Easier to transplant & 3 & 43 \\
\hline & $\begin{array}{l}\text { Less disease } \\
\text { incidences }\end{array}$ & 1 & 14 \\
\hline & Easier to transport & 2 & 29 \\
\hline & $\begin{array}{l}\text { High seedling } \\
\text { establishment }\end{array}$ & 1 & 14 \\
\hline & $\mathrm{N} / \mathrm{A}$ & 176 & \\
\hline \multirow[t]{3}{*}{ Duration of nursery } & Less than 4 weeks & 28 & 16 \\
\hline & More than 4 weeks & 37 & 21 \\
\hline & $\mathrm{N} / \mathrm{A}$ & & 63 \\
\hline
\end{tabular}




\subsubsection{Inputs for Tomato Production in Ghana}

Farmers who had access to irrigation used various types of irrigation to cultivate tomato across the regions in Ghana (Figure 9). In the Upper East region, flood or surface system or furrow irrigation $(28 \%)$ was widely used. Farmers in the Ashanti region and other regions fetched water in buckets to irrigate (19\%).

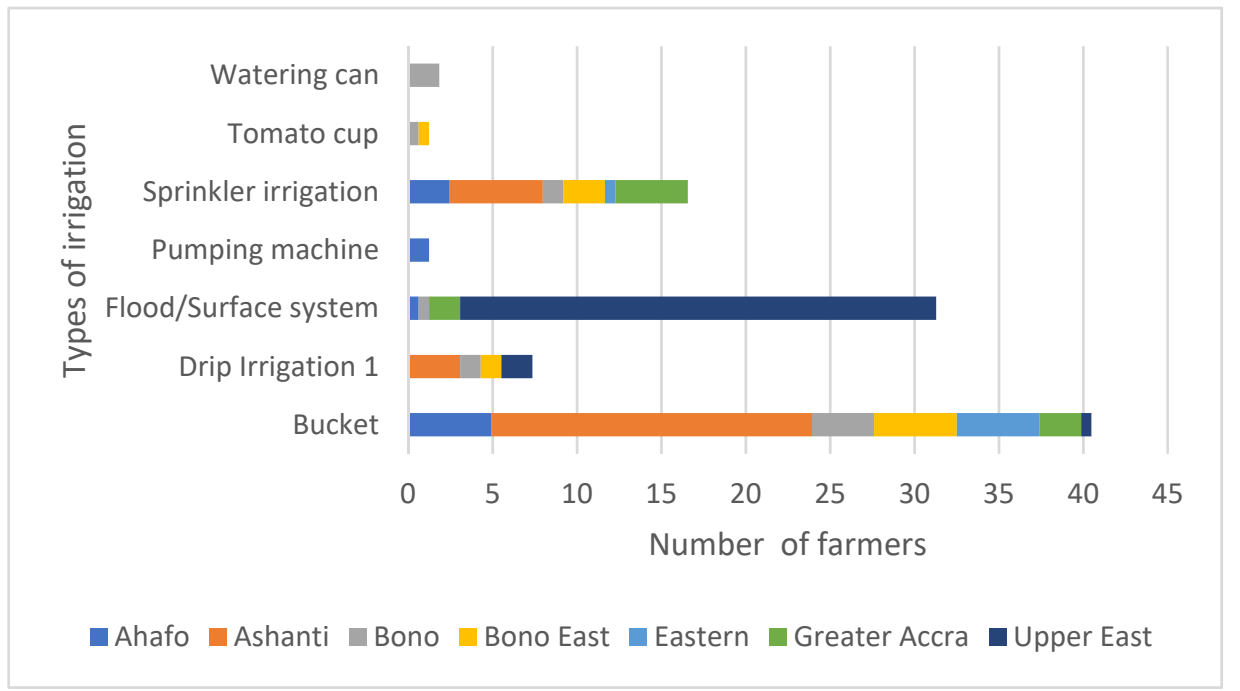

Figure 9. Types of irrigation methods used by tomato farmers in Ghana.

\subsection{Determinants of the Use of Improved Varieties}

The results revealed that gender and access to irrigation had positive and significant ( $p$-values $<0.05$ ) influence on the use of improved varieties (Table 7). As expected, being a male and having access to irrigation facilities increased the probability of using improved varieties by $19 \%$ and $51 \%$, respectively. This agrees with the IFPRI's report on considering gender in irrigation, whereby men have access to irrigation, but women lack access to irrigation facilities, even if both sexes are from the same household [35]. Farmers who had access to irrigation cultivated improved varieties, while farmers who did not have access to irrigation produced local cultivars [7]. Increased probability of using improved varieties for farmers who have access to irrigation was also reported for maize farmers in South Africa [36]. Males were found to be more likely to use improved varieties compared to females. This could be explained by the fact that tomato was primarily produced for the market, and males were more willing to invest in acquiring seeds of improved varieties. However, conversely to our findings, female farmers were found to be more likely to use improved maize varieties [36]. Access to training from extension agents and literacy had positive influence on the use of improved varieties, but that influence was not significant.

Table 7. Results of the logistic regression analysis.

\begin{tabular}{cccc}
\hline Variables & Average Marginal Effect & Std. Error & $\operatorname{Pr}(>|\mathbf{t}|)$ \\
\hline Intercept & 0.03 & 0.13 & 0.84 \\
Gender & 0.19 & 0.09 & 0.03 \\
Irrigation & 0.51 & 0.07 & 0.00 \\
Training & 0.09 & 0.09 & 0.31 \\
Education & 0.03 & 0.12 & 0.83 \\
\hline
\end{tabular}

Farmers used fertilizers, weed/pest/disease control products, and manure to cultivate tomato in Ghana (Table S2). The types of fertilizers used were either compound (vegetable mix, NPK) or Ammonium-N based Fertilizers (Top dressing). Farmers frequently used compound fertilizers (100\%) than ammonium-N fertilizers. Farmers apply fertilizers 
throughout the growing season; however, most of the fertilizer application is performed at planting and flowering stages. The use of organic manure is still marginal. Adoption of sustainable soil management practices by combining the use of inorganic and organic fertilizers should contribute to improving tomato production.

\subsection{Challenges of Tomato Production in Ghana}

Generally, the constraints of tomato production in sub-Saharan Africa include diseases, pests, low moisture stress, heat, and low soil fertility [1]. This study identified the following tomato production constraints in Ghana: diseases, pests, market, water, and weeds (Table S3). Other tomato production challenges included erratic rainfall pattern, low yield, unstable market prices, lack of machinery, and lack of fertilizers at the time of need.

\subsubsection{Tomato Diseases and Pests' Management Strategies}

The three most common tomato diseases identified by tomato farmers in Ghana were bacteria spot $(23 \%)$, target spot $(14 \%)$, and leaf curl (12\%), as indicated in (Table S3). Farmers identified the most common tomato pests as fruit worms, thrips, beet armyworms, whiteflies, aphids, grasshoppers, and spider mites.

\subsubsection{Tomato Diseases and Pests Control}

Farmers commonly used pesticides to control tomato diseases (81\%) and tomato insects (93\%) in Ghana (Table 8$)$. Some farmers combine application of pesticides and rotation $(4 \%)$ to manage diseases $(17 \%)$ and insects $(4 \%)$, while others used biological methods to manage both stresses. The most common weed management method used by farmers in Ghana is mechanical control (66\%), which involves the use of hoes. Some farmers use the combination of herbicides and mechanical control $(15 \%)$ or herbicide alone $(11 \%)$. Current pest management practices in tomato production in Ghana are non-sustainable.

Table 8. Management of tomato diseases and pests in Ghana.

\begin{tabular}{cccc}
\hline $\begin{array}{c}\text { Methods of Disease } \\
\text { and Pest Control }\end{array}$ & $\begin{array}{c}\text { Disease } \\
\text { Management (\%) }\end{array}$ & $\begin{array}{c}\text { Insects' }^{\prime} \\
\text { Management (\%) }\end{array}$ & Weed Management \\
\hline Use of pesticides & 81 & 93 & - \\
Rotation & 0 & 1 & - \\
Pesticides + rotation & 17 & 4 & - \\
Biological & 2 & 2 & 66 \\
Mechanical control & - & - & 15 \\
Herbicides + & - & - & 11 \\
mechanical control & - & - & 8 \\
Herbicide & - & - & \\
None & & &
\end{tabular}

The over-reliance on the use of pesticides is a serious concern for the safety of marketed tomatoes and the environment. For instance, farmers broadly classified many insecticides as DDT (Figure 10), an organochlorine which is banned in many countries [37]. Quantifying pesticides residues along tomato value chains will shed light on the extent of the problem and pave the way for the production of safe tomatoes. Alternative approach to overcome the overreliance on pesticides is the adoption of integrated pest management (IPM) approach. IPM involves the use of different methods of pest control in a manner that reduces the insect population to economic threshold or avoid damage levels that can cause severe loss. IPM systems involve monitoring pests, natural enemies, pesticide product substitution to improve yield, and sustainable crop production [38]. 


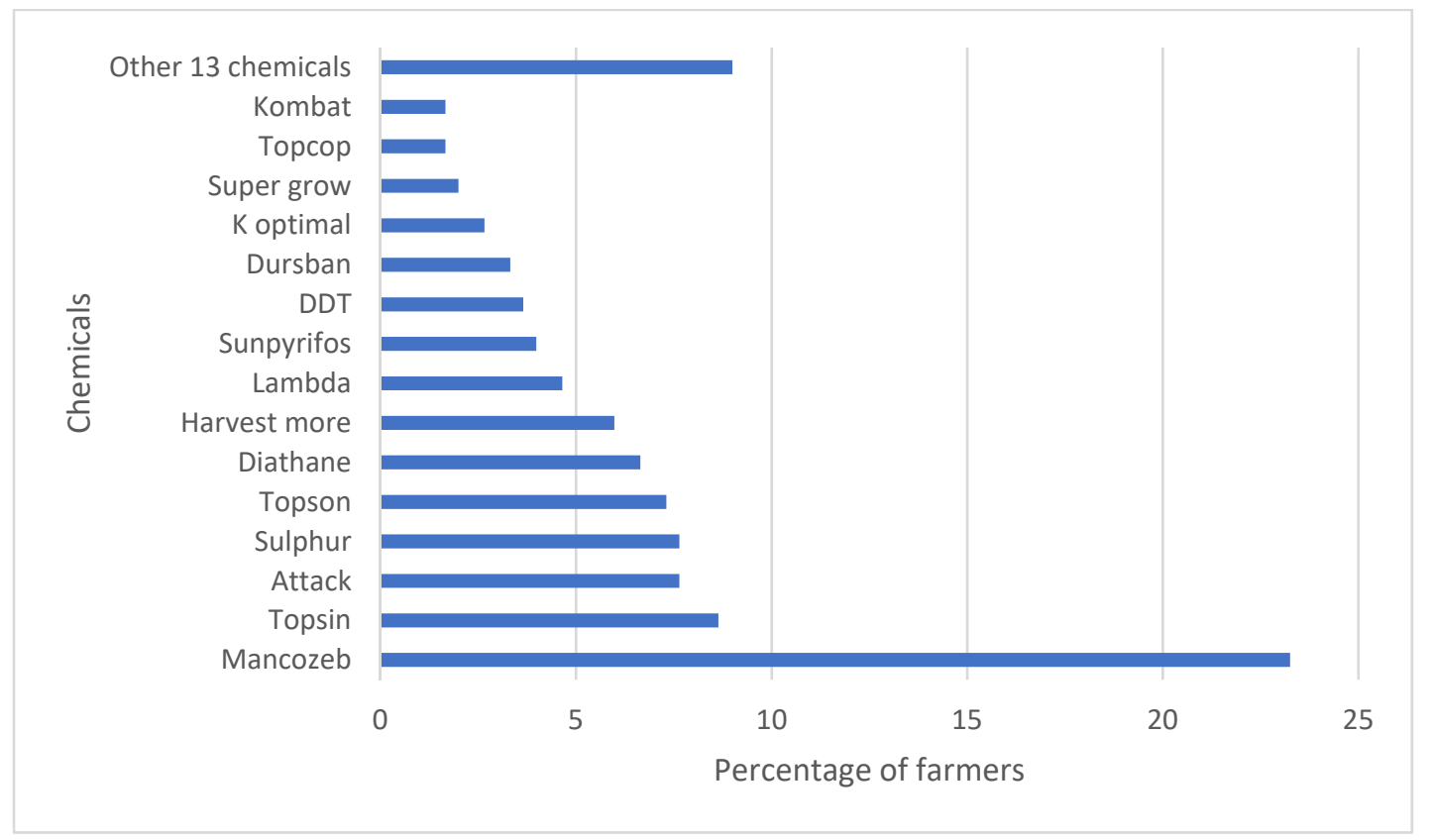

Figure 10. Common chemicals tomato growers use in controlling diseases, pests, and weeds Ghana.

The most common fungicide used included Mancozeb (fungicide), and the insecticides Topsin (Thiophanate-methyl) and Attack (Emamectin Benzoate). The high frequency of the use of Mancozeb, a broad-spectrum fungicide, could be an indicator of either limited availability of the fungicides or affordability or effectiveness.

\subsection{Tomato Yield Obtained by Farmers Based on Region and Gender}

There was a large variation in the tomato yields across and within regions (Figure 11). Average tomato yield varied from $6902.26 \mathrm{~kg} / \mathrm{ha}$ in the Bono region to $16,213.98 \mathrm{~kg} / \mathrm{ha}$ in the Bono East region. Across the seven regions, the average yield was 10,639.52 kg/ha. These values were consistent with the report of Robison and Kollavalli [7], who found that an average tomato yield of $10,600 \mathrm{~kg} /$ ha across three regions, namely the Greater Accra, Brong Ahafo, and Upper East regions. The average yields in our study and that of Robinson and Kolovalli [7] were higher than the estimate from FAO (4299.6 kg/ha in 2019), which could be explained either by the fact that these studies cover the major growing areas where yields could be higher than the other regions, or the lack of systematic nationwide data collection on tomato sector since the 1980s [4].

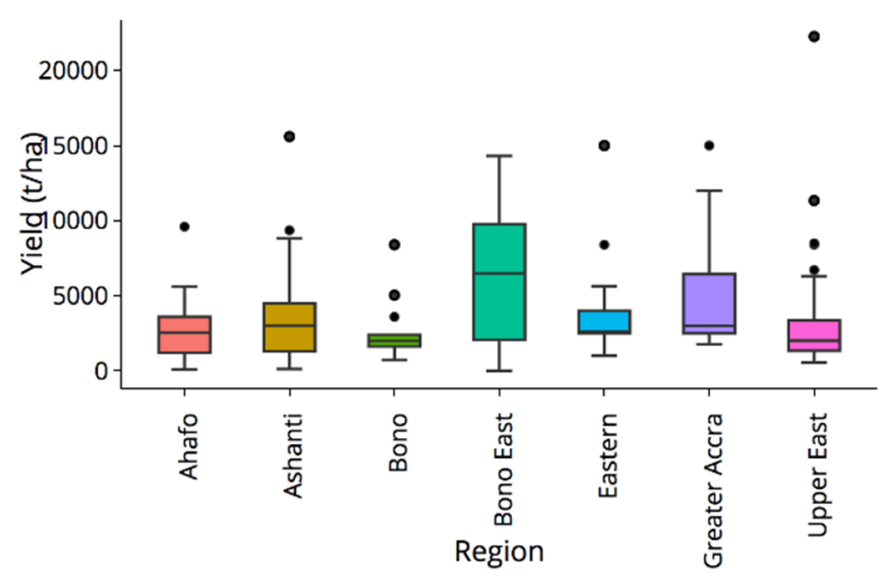

Figure 11. Box plot of average yield recorded by tomato farmers by region. 
We found no significant difference in yield between male and female tomato growers, based on Tukey's pairwise comparison (Figure 12).

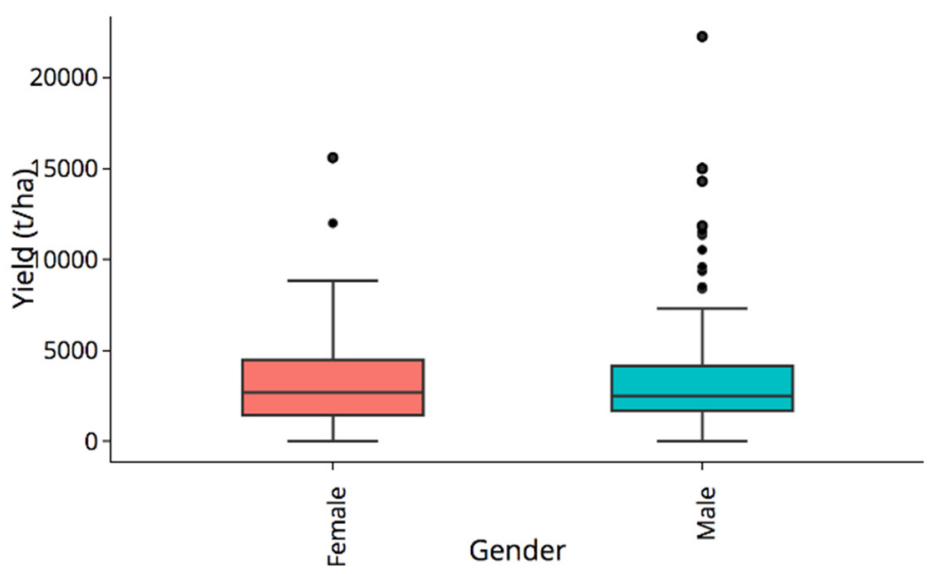

Figure 12. Box plot of average yield of tomato based on gender across regions.

\subsection{Harvest and Post-Harvest Handling}

Most of the tomato farmers in Ghana harvest tomato fruits when fully ripe (59\%) or red ripe (40\%), (Table S4). The stage of harvest of tomato could account for post-harvest loss of tomato, since there are no cold transportation or storage systems in most African countries. The number of weeks to maturity varies from eight weeks (25\%) to more than 12 weeks (2\%) after transplanting. Most tomato varieties were harvested at $12(59 \%)$ weeks after transplanting. Harvesting of fruits could last for one month (58\%) or three-four months (13\%). Tomato fruits were harvested twice a week (53\%) or once a week (45\%). Almost all of the tomato farmers (99\%) in the studied communities did not store the fruits after harvest. The produces were sold right after harvest to avoid or limit post-harvest loss, since they had no appropriate storage facility.

\subsection{Marketing and Transportation}

The main tomato market segments are fresh market and processing. The current demand for fresh tomato in Ghana is for the fresh market, since the processing factories are not active. The processing factories are inactive because of the lack of the right quality and quantity of fresh tomato [7]. The active processing plants import concentrates and repackage them for sale. It is important to note that the price of tomato per kilo of fresh tomato is higher than for processing. This makes fresh tomato production more profitable. Farmers who will supply to processing plants will not benefit from the price per kilo, but will benefit from the large quantity of tomato demand for processing. The tomatoes produced in our study locations were predominantly supplied to the local market (Table S5). The fruits were transported by road to the market or sold directly at the farm gate $(36 \%)$. The produce was mainly transported to the market by tricycle $(88 \%)$, vehicle $(8 \%)$, motorcycle $(3 \%)$, and bicycle $(1 \%)$. Coordinated marketing could increase the bargaining power of farmers. However, tomato marketing in Ghana was mostly done by farmers individually (81\%), while market co-coordination or group marketing $(19 \%)$ where the sale of the produce was conducted by Farmer Based Organization (FBO) was limited. Tomato farmers got marketing information from different sources. Market information was usually shared among farmers (55\%) or sourced from the Ministry of Food and Agriculture (32\%), buyers (9\%), and NGOs (4\%). 


\subsubsection{Challenges and Proposed Solutions to Tomato Marketing}

It is not surprising that the major tomato marketing challenges in Ghana were low farm-gate prices $(35 \%)$, which arose since almost all of the farmers harvested at the same period, causing oversupply and low demand for produce (19\%). Competition from other farmers $(14 \%)$ in the locality and other producing regions, as well as short shelf life of the produce (Table S5), were also challenges facing tomato marketing in Ghana. Other tomato marketing challenges included unstable prices and an unfair weighing scale from buyers, primarily because farmers do not have collective bargaining power. The farmers proposed solutions to the challenges of tomato marketing in Ghana, which included identifying other markets (33\%) such as processors and exporters, producing when demand is high (30\%) (that is, when there is less supply), group marketing to reduce costs of transport (11\%), and others (including standard price-setting per $\mathrm{kg}$, the establishment or revamping of processing factories, provision of cold storage facilities to temporarily store produce and reduce over-supply, and improvement of access roads to these communities to encourage buyers to visit the communities to buy their produce). Inferences can also be drawn from the marketing of crops such as cocoa, whereby an established organization buys and sells the produce on behalf of farmers

\subsubsection{Tomato Market Preference}

The farmers in the study area indicated that the fresh market prefers to buy medium $(49 \%)$ to large fruits $(51 \%)$ (Table 9). Tomato variety with high rounded and rounded fruit shapes were preferred by the market. The market preferred red fruits $(98 \%)$. It is important to note that the constitution of the buyers was $99 \%$ fresh fruit buyers. Industrial buyers were nonexistent, according to the responses from the study sample.

Table 9. Market preference of tomato fruits.

\begin{tabular}{ccc}
\hline Variable & N= 180 & Percentage \\
\hline Medium $(60-80 \mathrm{~g})$ & Fruit Size & \\
Large (above $80 \mathrm{~g})$ & 89 & 49 \\
& 91 & 51 \\
Flattened (oblate) & Fruit shape & 7 \\
Slightly flattened & 12 & 7 \\
Rounded & 12 & 26 \\
High rounded & 47 & 33 \\
Heart-shaped & 60 & 15 \\
Cylindrical (long oblong) & 27 & 2 \\
Pyriform & 3 & 8 \\
Ellipsoid (plum-shaped) & 15 & 2 \\
Yellow & 4 & 2 \\
Red & Fruit colour & 98 \\
Grand Total & 4 & 100 \\
\hline
\end{tabular}

\subsection{Profitability Analysis}

\subsubsection{Production Cost and Revenue}

The production cost varied widely among farmers in the seven regions studied (Table 10). The ratio between average total cost and variable cost was 0.87 . This ratio indicates that the average variable cost is $87 \%$ of the average total cost for tomato cultivation across the regions. 
Table 10. Cost components of tomato production in Ghana.

\begin{tabular}{lcccc}
\hline \multicolumn{1}{c}{ Cost } & Average & $\begin{array}{c}\text { Standard } \\
\text { Deviation }\end{array}$ & Minimum & Maximum \\
\hline Total production cost (GHS) & 5715 & 7285 & 340 & 55,570 \\
Variable cost (GHS) & 4995 & 6644 & 340 & 54,170 \\
Ratio variable cost to total cost & 0.87 & & & \\
\hline
\end{tabular}

The average total production cost was computed, as well as the average of each item cost used to calculate the percentage. The four most contributive variable cost to tomato production were labor $(31 \%)$, followed by compound fertilizers $(16 \%)$, chemicals $(13 \%)$, and seeds $(8 \%)$, Figure 13 . The highest proportion of labor cost confirmed that tomato production in Ghana, similar to in other parts of the world, is labor intensive [33,34]. According to information gathered from a focus group discussion (FGD), the current production practices required a lot of labor input for activities such as transplanting, watering, multiple spraying of chemicals, multiple fertilizer application, multiple weeding, and mound construction around the plants or earthing up and harvesting. It was also noted that without the application of fertilizers, the yield would be extremely low, hence farmers invest significantly into purchasing liquid and dry compound fertilizers. Chemicals such as fungicide and pesticides were necessary to ensure optimum plant performance. However, these pesticides and mineral fertilizers can be partially substituted with locally available organic manure and biopesticides for sustainable tomato production.

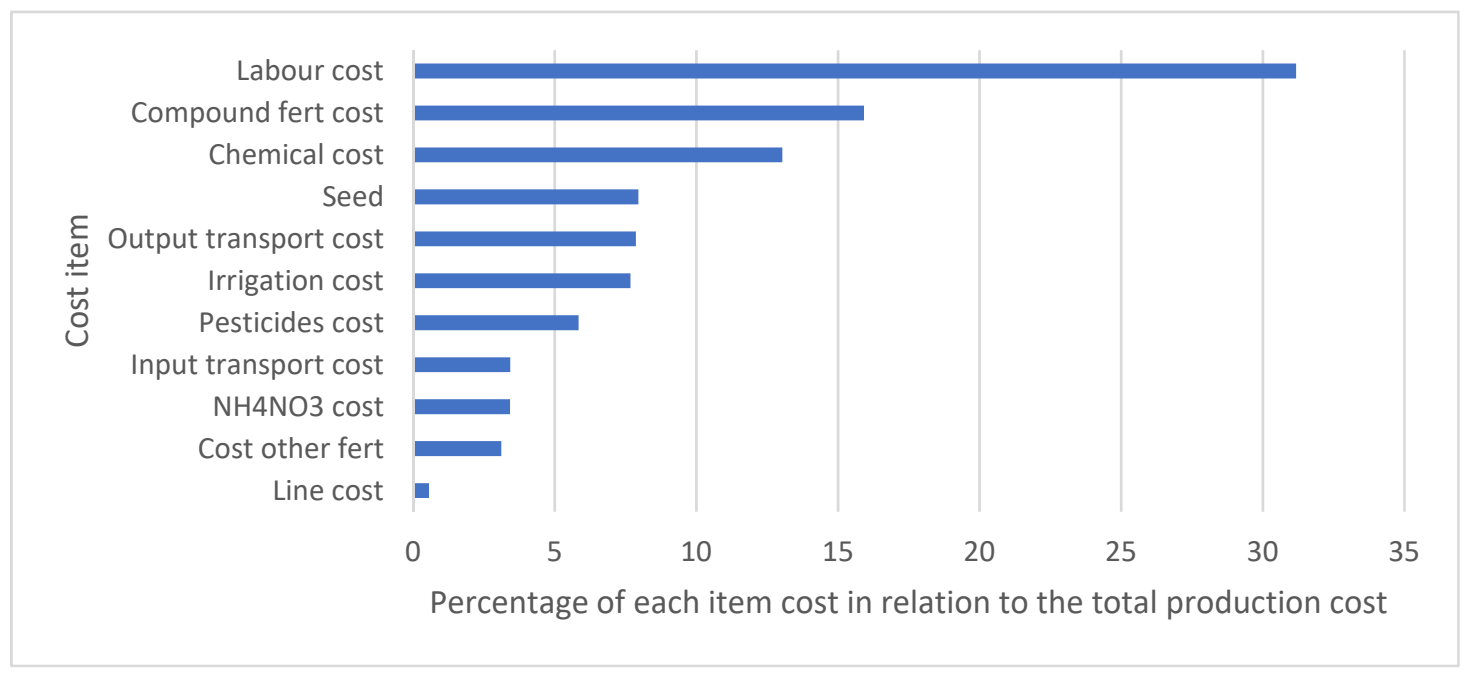

Figure 13. Relative importance of each variable cost in tomato production.

\subsubsection{Income and Profitability of Tomato Production}

Across the regions surveyed, farmers used land sizes ranging from under an acre to 42 acres for tomato farming (Table S6). However, it is important to note that a vast majority of the farmers interviewed ( $89 \%$ ) farmed five acres (2 hectares) and below of tomato. The cumulative percentage of the sample that cultivated up to three acres was $79.4 \%$. Thus, it is instructive to point out that most of the tomato farmers across the regions were smallholder farmers. The cost of tomato production across the regions surveyed ranged from GHS 340.00 (USD 59) to GHS 55,570.00 (USD 9588) (Table S7). It is essential to note that $88 \%$ of the farmers interviewed indicated that their total production cost ranged from GHS 340.00 to GHS 9500.00, and most of these farmers had tomato farm sizes of five acres and smaller. A cumulative $50 \%$ of respondents spent amounts ranging from GHS 340.00 to 3500.00 on the production of tomato for the whole season. The mode for the total cost of production was GHS 5000.00, bringing the cumulative percentage for farmers who spent from GHS 340.00 to 5000.00 to $69 \%$. Only $12 \%$ of the sample interviewed had the total production cost 
hovering between GHS 10,000.00 and GHS 55,570.00. Almost all of these high input cost farmers were those with acreage of tomato cultivation of 7 to 42 acres (Table S8).

The income from tomato production for the respondents interviewed ranged from less than GHS 1000.00 (USD 173) to over GHS 30,000.00 (USD 5176) (Table 11). The income range that most farmers indicated receiving was GHS 5000.00-GHS 10,000.00. Clearly, if a cumulative $88 \%$ of smallholder farmers (less than 2 hectares) interviewed invested between GHS 340.00-9500.00 and a cumulative 55\% received between GHS 1000-10,000.00, then some of these smallholder farmers were barely making a profit. However, it is important to note that farmers whose total cost of production fell below the GHS 5001.00 (69\% of farmers) would have likely made some considerable profits if they earned between GHS $5000.00-10,000.00$. It is worth noting that $33 \%$ of respondents received incomes between GHS 10,001.00 to 30,000.00, amounts exceeding the upper limit (GHS 9500.00) of the total cost of production for the approximately $88 \%$ of the farmers. If it is assumed that $88 \%$ of farmers invested between GHS 340.00-95,00.00, and yet the same $88 \%$ of farmers received income ranging from less than GHS 1000.00 to GHS 30,000.00, then the tomato cultivation as a business indicates profitability across the regions surveyed.

Table 11. Income earned by farmers from tomato production from 2019 season in GHS.

\begin{tabular}{cccc}
\hline $\begin{array}{c}\text { Income Ranges in } \\
\text { GHS }\end{array}$ & Frequency & Valid Percent & Cumulative Percent \\
\hline$<1000$ & 9 & 5.1 & 5.1 \\
$2001-3000$ & 19 & 10.7 & 15.7 \\
$3001-5000$ & 27 & 15.2 & 30.9 \\
$5001-10,000$ & 43 & 24.2 & 55.1 \\
$10,001-20,000$ & 37 & 20.8 & 75.8 \\
$20,001-30,000$ & 22 & 12.4 & 88.2 \\
$>30,000$ & 21 & 11.8 & 100.0 \\
Total & 178 & 100.0 & \\
System & 2 & & \\
Total & 180 & & \\
\hline
\end{tabular}

The average selling price per $\mathrm{kg}$ (Table 12) was among the main reasons accounting for some farmers' low income from tomato cultivation. A glut during the harvesting period drives the price downward.

Table 12. Average selling price of a kilo of tomato and total income earned based on gender from 2019 season.

\begin{tabular}{ccccc}
\hline Average Selling Price & Male & Female & Grand Total & Fisher Exact Test \\
\hline Less than GHS 4/kg & 47 & 12 & 59 & \\
GHS 4.1-5/kg & 18 & 2 & 20 & \\
GHS 5.1-10/kg & 15 & 3 & 18 & \\
GHS 15.1-20/kg & 1 & 1 & 1 & \\
More than GHS 20/kg & 2 & 0 & 2 & \\
Grand Total & 81 & 19 & 100 & \\
Income & 2 & 3 & 5 & \\
Less than GHS 1000 & 8 & 3 & 11 & \\
GHS 2001-3000 & 12 & 3 & 15 & \\
GHS 3001-5000 & 20 & 4 & 24 & \\
GHS 5001-10,000 & 19 & 2 & 21 & \\
GHS 10,001-20,000 & 10 & 2 & 12 & \\
GHS 20,001-30,000 & 11 & 1 & 12 & \\
More than 30,000 & 81 & 19 & 100 & \\
Grand Total & & & & \\
\hline
\end{tabular}




\section{Conclusions and Recommendations}

Tomato farming is an important source of income for farmers. Tomato production is dominated by smallholder farmers, and it is mostly rainfed. Key varietal preferences for tomato were identified. This is critical to guide a successful introduction or development of varieties. Access to production factors is still a challenge but there is a discrepancy among regions. Ahafo, Ashanti, Bono, Bono East, and Eastern regions critically lack necessary irrigation facilities to boost vegetable production. Across regions, farmers have more or less fair access to fertilizers, especially compound fertilizers. Access to a diversity of improved varieties and high-quality seeds was incredibly low. Farmers have cultivated the habit of purchasing seeds. This presents a business opportunity for growing the seed business in Ghana and sustainable tomato production. Poor management of pests and diseases is constraining vegetable production. Almost all of the harvested produce is sold on local markets. Farmers have low control over the prices of their produce, as this is often set by middlemen who control the prices. Farmers' inability to access storage facilities forces them to sell produce right after harvest leading to low returns on investments. Despite these marketing challenges, tomato production is profitable, since some farmers made as much as $100 \%$ or double profit on their investments. Our study shed light on tomato production practices along with constraints faced by value chain actors. Knowledge gained on these practices could guide tailored interventions to improve tomato production and marketing in Ghana.

Based on the production and marketing challenges, the following recommendations were formulated:

- Exploit the ownership of mobiles phones by vegetable growers to improve access to good agronomic practices and market information;

- Increase farmers' awareness of improved varieties by facilitating access to irrigation; Interventions to promote the use of improved varieties should be inclusive and ensure they are not gender-biased;

- Increase investment into introducing or breeding adapted vegetable varieties to meet the challenges of growing conditions. For instance, breeding for insect resistant varieties will decrease the use of pesticides, and hence promote a more sustainable tomato production;

- Seed distributors should move closer to farmers for increased availability of highquality seeds. Besides seeds sale, seed dealers should offer critical information on good agronomic practices that will enable farmers to optimize their production;

- Improvement in irrigation to enable farmers to grow vegetables year-round or in off-season especially in Ahafo, Ashanti, Bono, Bono East, and Eastern regions;

- Strengthen the capacity of farmers on integrated diseases and pests' management for sustainable tomato production;

- Improve storage facility for vegetables to enable farmers to sell them produces at the desired period and increase their profit margins.

Supplementary Materials: The following supporting information can be downloaded at: https: / / www.mdpi.com/article/10.3390/su14031436/s1, Table S1. List of tomato production regions, districts and villages studied in Ghana. Table S2. Types of farm inputs and time of fertilizer application in Ghana. Table S3. Tomato production constraints, common diseases, and pests. Table S4. Harvest and post-harvest handling of tomato in Ghana. Table S5. Tomato marketing, constraints, and proposed solutions. Table S6. Land size for tomato. Table S7. Total cost of Tomato Production. Table S8. Large scale and high input farmers.

Author Contributions: Conceptualization, D.T., G.M. and L.D.M.; methodology, G.M., D.T., L.D.M and M.A.T.A.; software, L.D.M. and M.A.T.A.; validation, L.D.M. and M.A.T.A.; formal analysis, L.D.M. and M.A.T.A.; investigation, L.D.M. and M.A.T.A.; resources, L.D.M., M.A.T.A., D.T., G.M., P.A., A.D. and E.Y.D.; data curation, L.D.M. and M.A.T.A.; writing-original draft preparation, L.D.M. and M.A.T.A.; writing-review and editing, L.D.M., M.A.T.A., D.T., G.M., P.A., A.D. and E.Y.D.; visualization, L.D.M. and M.A.T.A.; supervision, D.T., G.M., P.A., A.D. and E.Y.D.; project 
administration, L.D.M., M.A.T.A., D.T., G.M., A.D. and E.Y.D.; funding acquisition, D.T. and G.M. All authors have read and agreed to the published version of the manuscript.

Funding: This research was funded by SNV-Hortifresh and African Agricultural Technology Foundation (AATF).

Institutional Review Board Statement: Not applicable.

Informed Consent Statement: Not applicable.

Data Availability Statement: The data presented in this study are available on request from the corresponding author.

Acknowledgments: We are thankful to the management and staff of the West Africa Centre for Crop Improvement (WACCI) and the African Agricultural Technology Foundation (AATF) for the administrative support in carrying out this research.

Conflicts of Interest: The authors declare no conflict of interest.

\section{References}

1. Fufa, F.; Hanson, P.; Dagnoko, S.; Dhaliwal, M.; Africa, C. AVRDC—The World Vegetable Center Tomato Breeding in Sub-Saharan Africa: Lessons from the Past, Present Work, and Future Prospects. Acta Hortic. 2011, 911, 87-98. [CrossRef]

2. Sibomana, M.S.; Workneh, T.S.; Audain, K. A review of postharvest handling and losses in the fresh tomato supply chain: A focus on Sub-Saharan Africa. Food Secur. 2016, 8, 389-404. [CrossRef]

3. FAOSTAT Online Statistical Database of the Food and Agriculture Organization of the United Nations. Available online: http:/ / www.fao.org/faostat/en/\#data/TP (accessed on 1 October 2021).

4. Asselt, J.V.; Masias, I.; Kolavalli, S. Competitiveness of the Ghanaian Vegetable Sector Findings from a Farmer Survey. Ghana Strateg. Support Progr. GSSP Work. Pap. 2018, 47, 1-24.

5. International Food Policy Research Institute (IFPRI). Ghana's Tomato Market. MoFA-IFPRI Market Brief 3; IFPRI: Washington, DC, USA, 2020; pp. 1-4. [CrossRef]

6. Trade Economy Annual International Trade Statistics by Country. Available online: https://trendeconomy.com/data/h2/Ghana/ 0702 (accessed on 10 February 2021).

7. Robinson, E.J.Z.; Kolavalli, S.L. The Case of Tomato in Ghana: Productivity. Ghana Strategy Support Program (GSSP); GSSP Working Paper No. 19. 2010, pp. 1-9. Available online: gssp.ifpri.info/files/2010/08/gsspwp191.pdf (accessed on 1 October 2021).

8. Gonzalez, Y.S.; Dijkxhoorn, Y.; Elings, A.; Glover-Tay, J.; Koomen, I.; van der Maden, E.C.L.J.; Nkansah, G.; Obeng, P. Vegetables Business Opportunities in Ghana; Wageningen UR: Wageningen, The Netherlands, 2014.

9. Kugblenu, Y.O.; Oppong-Danso, E.; Ofori, K.; Andersen, M.N.; Abenney-Mickson, S.; Sabi, E.B. Screening tomato genotypes for adaptation to high temperature in West Africa. Acta Agric. Scand. Sect. B Soil Plant Sci. 2013, 63, 516-522. [CrossRef]

10. Ayenan, M.A.T.; Danquah, A.; Agre, P.A.; Hanson, P.; Asante, I.K.; Danquah, E.Y. Genomic and phenotypic diversity of cultivated and wild tomatoes with varying levels of heat tolerance. Genes 2021, 12, 503. [CrossRef]

11. Melomey, D.L.; Danquah, A.; Offei, K.S.; Ofori, K.; Danquah, E.; Osei, M. Review on Tomato (Solanum lycopersicum, L.) Improvement Programmes in Ghana. Recent Adv. Tomato Breed. Prod. 2019. [CrossRef]

12. Nanii, Y.; Isaac, A.; Evelyn, D.A. An efficiency assessment of irrigated tomato (Solanum lycopersicum) production in the Upper East Region of Ghana. J. Dev. Agric. Econ. 2020, 12, 1-8. [CrossRef]

13. Jumpah, E.T.; Adams, A.; Ayeduvor, S. Estimating yield and income effects of formal credit-based programme among tomato farmers in the Greater Accra Region of Ghana. Sci. Afr. 2020, 9, e00499. [CrossRef]

14. Pham, P.; Dorey, A.; Musaraj, P.; Patrick-Vinck, F.E.; Kreutzer, T. KoBoToolbox at the Harvard Humanitarian Initiative. Available online: https:/ / kobotoolbox.org/ (accessed on 10 June 2021).

15. KoBoCollect. 2021. Available online: https://play.google.com/store/apps/details?id=org.koboc.collect.android\&hl=en (accessed on 10 June 2021).

16. Julkowska, M.M.; Saade, S.; Gao, G.; Morton, M.J.L.; Awlia, M.; Tester, M.A. mmjulkowskwa/MVApp.pre-Release_v2.0. 2017. Available online: https://zenodo.org/record/1067974 (accessed on 1 October 2021).

17. R Core Team. A Language and Environment for Statistical Computing; R Foundation for Statistical Computing: Vienna, Austria; Available online: https:/ / www.R-project.org/ (accessed on 1 October 2021).

18. Ghana Statistical Service Ghana Living Standard Survey (Glss 7). 2018; pp. 1-8. Available online: https://www2.statsghana.gov. gh/nada/index.php/catalog/97/study-description (accessed on 1 October 2021).

19. Osei, M.K.; Danquah, A.; Blay, E.; Danquah, E.; Adu-dapaah, H. Stakeholders' perception and preferences of post-harvest quality traits of tomato in Ghana. Sustain. Agric. Res. 2018, 7, 93-109. [CrossRef]

20. Nelson, R.; Richard, P.S.E. Investment in Humans, Technological Diffussion and Economic Growth. Am. Econ. Rev. 1966, 56, 69-75.

21. Reimers, M.; Klasen, S. Revisiting the Role of Education for Agricultural Productivity. Am. J. Agric. Econ. 2013, 95, 131-152. [CrossRef] 
22. Morris, M.L.; Doss, C.R. How does gender affect the adoption of agricultural innovations? The case of improved maize technology in Ghana. Agric. Econ. 2004, 25, 27-39.

23. Quisumbing, A.R.; Payongayong, E. Women's Land Rights in the Transition to Individualized Ownership: Implications for Tree-Resource Management in Western Ghana. Econ. Dev. Cult. Chang. 2001, 50, 157-182. [CrossRef]

24. Yokying, P.; Lambrecht, I. Land Use Policy Landownership and the gender gap in agriculture: Insights from northern Ghana. Land Use Policy 2020, 99, 105012. [CrossRef]

25. Kudadze, S.; Imoru, A.J.; Adzawla, W. Farmers' Perception on Irrigation Farming and the Factors Influencing Access to and Size of Irrigable lands in Northern Region, Ghana. Asian Food Sci. J. 2019, 8, 1-14. [CrossRef]

26. Balana, B.B.; Bizimana, J.; Richardson, J.W.; Lefore, N.; Adimassu, Z.; Herbst, B.K. Economic and food security effects of small-scale irrigation technologies in northern Ghana. Water Resour. Econ. 2020, 29, 100141. [CrossRef]

27. Issahaku, H.; Abu, B.M.; Nkegbe, P.K. Does the Use of Mobile Phones by Smallholder Maize Farmers Affect Productivity in Ghana? J. Afr. Bus. 2018, 19, 302-322. [CrossRef]

28. Haile, K.K.; Tirivayi, N.; Tesfaye, W. Farmers' willingness to accept payments for ecosystem services on agricultural land. Ecosyst. Serv. 2019, 39, 100964. [CrossRef]

29. Krell, N.T.; Giroux, S.A.; Guido, Z.; Hannah, C.; Lopus, S.E.; Caylor, K.K.; Evans, T.P. Smallholder farmers' use of mobile phone services in central Kenya. Clim. Dev. 2021, 13, 215-227. [CrossRef]

30. Gebre, G.G.; Isoda, H.; Rahut, D.B.; Amekawa, Y.; Nomura, H. Gender differences in agricultural productivity: Evidence from maize farm households in southern Ethiopia. GeoJournal 2019, 86, 843-864. [CrossRef]

31. USDA. Report Name: Planting Seeds Report; GH2020-000; 2020. Available online: https://apps.fas.usda.gov/newgainapi/api/ Report/DownloadReportByFileName?fileName=Planting\%20Seeds_Accra_Ghana_04-07-2020 (accessed on 1 October 2021).

32. Bold, T.; Svensson, K.C.K.J.; Yanagizawa-Drott, D. Lemon Technologies and Adoption: Measurement, Theory, and Evidence from Agricultural Markets in Uganda. Q. J. Econ. 2017, 132, 1055-1100. [CrossRef]

33. Gonzalez, Y.S.; Dijkxhoorn, Y.; Koomen, I.; van der Maden, E.; Herms, S.; Joosten, F.; Mensah, S.A. Vegetable Business Opportunities in Ghana; Wageningen UR: Wageningen, The Netherlands, 2016.

34. Anatole, M.; Ayenan, T.; Danquah, A.; Ahoton, L.E.; Ofori, K. Utilization and farmers' knowledge on pigeonpea diversity in Benin, West Africa Utilization and farmers' knowledge on pigeonpea diversity in Benin, West Africa. J. Ethnobiol. Ethnomed. 2017, 13, 37. [CrossRef]

35. Bryan, E.; Didi, H.E. Research Post Considering Gender in Irrigation: Meeting the Challenges Women Farmers Face in Technology Adoption; IFPRI, 2019. Available online: https:/ / www.ifpri.org/blog/considering-gender-irrigation-meeting-challenges-women-farmersface-technology-adoption (accessed on 1 October 2021).

36. Sinyolo, S. Technology adoption and household food security among rural households in South Africa: The role of improved maize varieties. Technol. Soc. 2020, 60, 101214. [CrossRef]

37. Donkor, A.; Osei-Fosu, P.; Dubey, B.; Kingsford-Adaboh, R.; Ziwu, C.; Asante, I. Pesticide residues in fruits and vegetables in Ghana: A review. Environ. Sci. Pollut. Res. 2016, 23, 18966-18987. [CrossRef]

38. Pretty, J.; Bharucha, Z.P. Integrated pest management for sustainable intensification of agriculture in Asia and Africa. Insects 2015, 6, 152-182. [CrossRef] 